\title{
Effect of Exogenous $\alpha$-Tocopherol on Sweet Pepper Plants Irrigated by Diluted Sea Water
}

\author{
Sahar S. Taha \\ Vegetable Crops Department, Faculty of Agriculture, \\ Cairo University, El-Gama St. 9, 12613 Giza, Egypt. \\ Abdel Wahab M. Mahmoud \\ Plant Botany Department, Plant Physiology division, \\ Faculty of Agriculture,Cairo University, El-Gama St. 9, 12613 Giza, Egypt. \\ Mostafa M. Rady \\ Botany Department, Faculty of Agriculture, \\ Fayoum University, 63514 Fayoum, Egypt.
}

Received: October 30, 2017

Accepted: November 15, 2017

doi:10.5296/jas.v6i1.12365

URL: https://doi.org/10.5296/jas.v6i1.12365

\begin{abstract}
Capsicum annum is one of the most cultivated summer crops in Egypt which is consider the most susceptible crop to harsh a biotic stresses as Salinity condition. Pots experiment was carried out at Faculty of Agriculture, Fayoum University, Egypt during two successive summer seasons of 2014 and 2015 to study the responsive of Sweet pepper (cv. California wonder) plants irrigated by diluted sea water $\left(\mathrm{EC}=8.0 \mathrm{dSm}^{-1}\right)$ to foliar applications of $1 \mathrm{mM}$ alpha-Tocopherol ( $\alpha$ TOC). Four treatments were arranged in a randomized block design:1) plants irrigated by sea water (SW) and sprayed by tap water (TW), 2) TW for irrigation and $\alpha$ TOC for foliar spray, 3) SW for irrigation and $\alpha$ TOC for foliar spray and 4) the control (TW for irrigation and foliar spray). Pepper plants irrigated by sea water recognized significant reductions in growth parameters (leave number, leaf area, plant dry weight, Fruit number and Fruit yield). Results also showed that, foliar application of pepper plant with aTOC caused a notable upgrading in growth and yield under saline conditions. The maximum increased growth was obtained when plants irrigated by TW and sprayed by $1 \mathrm{mM} \alpha \mathrm{TOC}$. The foliar
\end{abstract}


application of $\alpha$ TOC considerably boosted the activities of Superoxide dismutase (SOD), Catalase (CAT), Ascorbate peroxidase (APX) and Glutathione reductase (GR) of pepper plants contrasted to control treatment. The outcome of present experiment could be recommended for both new reclaimed lands suffering from salt water and regions exposure to salinity hazard in irrigated water.

Keywords: Alpha-Tocopherol, Capsicum annum, growth parameters, Enzymes activity, Saline water, Yield.

\section{Introduction}

Capsicum annиum, bell, sweet, or chili pepper with cultivated varieties containing bell, sweet, chili, and paprika peppers is a perennial herbaceous plant belong to Solanaceae, which originated in Central and South America and was cultivated over 5,000 years ago (Kraig et al., 2006). Peppers from $C$. annuum have been elaborated into numerous varieties that are presently cultivated over a wide area for sweet and hot cultivars of green and red bell pepper and chili pepper, that are one of the most common used spices in the world, with dry forms containing paprika, chili powder and cayenne (Castanon-Najera et al., 2008; Perez-Castañeda et al., 2008 and Prado, 2008). In Egypt, Capsicum annum is consider one of the mainly cultivated vegetable crop in summer season in new reclaimed land, which suffer from salinity, low productivity, and reduce soil building. Therefore, these adverse environments affect plants development and resulted in reduce yield. Capsicum annum is particularly susceptible to drought damages and is moderately susceptible to salinity (Rhoades et al., 1992). (Semiz et $a l ., 2014)$ mentioned that yield decreased once irrigation water salinity become more than EC $2 \mathrm{dS} \mathrm{m}^{-1}$. Approximately one-third of the 260 million hectares of irrigated soil worldwide, soil that provide $40 \%$ of the total food productivity is affected by salinization (United Nations, 2011). For instance, e.g., Egypt, Pakistan, India, the United States and Australia have saline land and drainage between 15 and $36 \%$ of their irrigated areas and are thereafter devoting real resources to clear this matter (Schwabe et al., 2006).

Salinity caused a decrease in yield that is caused by adverse stimuli in water relations, thus initiating an ion unbalance in plants, which could cause ion toxicity (Munns et al., 2006), osmotic stress and exchanges to biochemical response in plants (Khan et al., 2013), as well as it could effect in alimentation unbalance (Liu and Zhu 1998). Salinity can cause membrane instability of the photosynthetic apparatus (Munns and Termaat 1986), in addition to irreversible damage to cells and tissues (Meyer and Boyer, 1981).Salt stress decreases photosynthetic apparatus, plant development, and stimulates the activity of an antioxidant system (Rao,2006; Rady, 2011; Rady et al., 2013; Semida et al., 2014; Semida and Rady, 2014).This problem-induced salinization is due to the triggering of oxidative stress in plant cells through an over reproduction of reactive oxygen species (ROS), successively damage proteins, DNA and lipids (Yasar et al., 2006). Chloroplasts are the organelles delivering the ROS such as the superoxide radical $\left(\mathrm{O}_{2}\right)$ hydrogen peroxide $\left(\mathrm{H}_{2} \mathrm{O}_{2}\right)$ and singlet oxygen $\left(\mathrm{O}_{1}\right)$ through photosynthesis (Asada, 1992). ROS cause photo-degradation and membrane lipid peroxidation (Yildrimin et al., 2008). To relieve these salt toxicity, plants develop numerous mechanisms to make their tolerance, thus protecting their cells and sub-cellular from the toxic 
effects of ROS with together, enzymatic and non-enzymatic antioxidant biological systems (Sairam and Srivastava, 2001; Mishra et al., 2009), containing ion homeostasis, osmotic modification, stress damage control and repair, and growth regulation (Zhu, 2002), salt stressed plants can osmotically modify to reduce theouter water potential by store toxic ions in the vacuole and by synthesizing compatible solutes in the cytoplasm (Hasgawa et al., 2000). In addition the activation of the reactive oxygen scavenging system and regulation of cell growth rate can occur (Maggio et al., 2002).Such metabolic reaction allows acclimation to osmotically unfavorable environments but can decrease the final yield.

In addition to the physiological mechanisms of plants, various cultural methods are being used to reduce the harm effects of salinity on crop yield, for example, reproduction salinity resistant cultivars (Yang et al., 2005), utilizing grafting methods on vegetable plants (Estan et al., 2005 and Edelstein et al., 2005), spraying growth substance (Hamdia et al., 2004), soil elaboration (Bacilio et al., 2004), using organic fertilizers (Rady, 2012), humic substances application (Arancon et al., 2006), applying of antioxidants such as ascorbic acid (Ejaz et al. 2012) and alpha-tocopherol (Abdallah et al., 2013,Semida et al., 2014 and Semida et al., 2016). Alpha-tocopherol ( $\alpha$ TOC) is a low molecular weight lipophilic membrane-located antioxidant. It keeps cell membranes from oxidation (Asada, 1999) and polyunsaturated fatty acids from lipid peroxidation (Krieger-Liszkay and Trebst, 2006), it also has the potential to improve membrane stability, integrity and permeability. furthermore, $\alpha \mathrm{TOC}$ has been shown to give an optimum conditions for the photosynthetic apparatus (Wise and Naylor, 1987), applying of aTOC was demonstrated to significantly improve salt tolerance in onion plants by reducing the endogenous lipid peroxidation and $\mathrm{H}_{2} \mathrm{O}_{2}$, at the same time increasing enzymatic for example superoxide dismutase, catalase, ascorbate peroxidase, and glutathione reductase and non-enzymatic for example ascorbic acid and glutathione beside antioxidant activity (Semida et al., 2016). Applying of $\alpha \mathrm{TOC}$ at different concentrations led to decreases in $\mathrm{Na}$ and $\mathrm{Cl}$ and increase in $\mathrm{Ca}, \mathrm{K}, \mathrm{Mg}$ and $\mathrm{P}$ relative to controls. Exogenous applications of aTOC caused marked encouragement in yield attributes on three cultivars of flax plant (Linum usitatissimum L.) (Sadak and Dawood 2014), moreover aTOC treated bean plants grown under varying conditions, had enhanced all growth parameters and yield and its components compared to control plants. Other factors such as, performance index, relative water content, membrane stability index, nutrients status and their relations, stem and leaf parameters were enriched in $\alpha$ TOC treated plants, in comparison to untreated plants (Semida et al., 2014). The supplementation of $0.1 \mathrm{~g} \mathrm{l}^{-1} \alpha \mathrm{TOC}$ on soybean plants was shown to increase the rate of photosynthesis, growth rate, and $\mathrm{N}$ contents, (Rady et al., 2015). When the influence of $\alpha \mathrm{TOC}$ was carried out on sunflowers in saline conditions, the results showed an enhancement in both plant development and its yield (Sadak et al., 2010).

This study was carried out with the primary objective of assessing the response of pepper plants irrigated with diluted sea water $\left(\mathrm{EC}=8.0 \mathrm{dSm}^{-1}\right)$ to foliar applications of $1 \mathrm{mM} \alpha \mathrm{TOC}$. It was a major aim to investigate the effects of $\alpha$ TOC and diluted sea water on the growth, yield, concentrations of photosynthetic pigments in leaves, non-enzymatic antioxidants, and osmoprotectants ( $\alpha$-tocopherol, ascorbic acid, glutathione), $\mathrm{K}, \mathrm{Ca}, \mathrm{Na}$, as well as their relation with $\mathrm{Na}$. The activities of superoxide dismutase, catalase, ascorbate peroxidase, 
glutathione reductase and tissue health (relative water content and membrane stability index) were also overviewed.

\section{Materials and Methods}

\section{Plant Experiments}

In a greenhouse, two pot experiments were conducted during the summer seasons of 2014 and 2015 at the Faculty of Agriculture, Fayoum University, Southeast Fayoum, Egypt. The climate conditions were as follows: daytime temperatures ranging from 29.8 to $39.6{ }^{\circ} \mathrm{C}$, with an average of $34.7 \pm 2.3{ }^{\circ} \mathrm{C}$, night temperatures ranging from 18.4 to $24.8{ }^{\circ} \mathrm{C}$, with an average of $21.6 \pm 1.4{ }^{\circ} \mathrm{C}$ and the daily relative humidity ranged from 38 to $76 \%$ with an average value of $57 \pm 5.8 \%$.

Sweet pepper (cv. California wonder) seedlings (45 day old hold 6-7 leaves/ plant) were obtained from a privet outlet. Two healthy seedlings were transplanted in $50 \mathrm{~cm}$-diameter plastic pot that contains $12 \mathrm{~kg}$ sandy loam soil. According to the recommended doses, $2.5 \mathrm{~g}$ nitrogen $(\mathrm{N})$ as ammonium sulphate $(20.5 \% \mathrm{~N}), 1.5 \mathrm{~g}$ phosphorous $(\mathrm{P})$ as calcium superphosphate $\left(15.5 \% \mathrm{P}_{2} \mathrm{O}_{5}\right)$, and $1.0 \mathrm{~g}$ potassium $(\mathrm{K})$ as potassium sulphate $\left(48 \% \mathrm{~K}_{2} \mathrm{O}\right)$ were added to each pot before planting. Ammonium sulphate of $1.50 \mathrm{~g}$ as supplementary doses was added at 30, 60, and 120 days after transplantation for each pot.

In every season, four treatments were arranged in a randomized block design with 30 replicate, as 1) diluted sea water (EC $8.0 \mathrm{dS} \mathrm{m}^{-1}$ ) for irrigation and tap water (EC $0.22 \mathrm{dS} \mathrm{m}^{-1}$ ) for foliar spray, 2) tap water for irrigation and $\alpha$-tocopherol $(\alpha$-TOC; $1 \mathrm{mM}$, Hangzhou Toyond Biotech Co. Ltd., Zhejiang, P. R. China) for foliar spray, 3) sea water for irrigation and $\alpha \mathrm{TOC}_{1.0}$ for foliar spray, and 4) control (tap water for irrigation and foliar spray). Fifteen days after transplantation, all pots were sprayed three-times at 15 days intervals with tap water or $1 \mathrm{mM} \alpha$-TOC. The $1 \mathrm{mM} \alpha$-TOC was chosen as the best spraying level based on a preliminary study where $0.5,1.0,1.5$ or $2.0 \mathrm{mM} \alpha$-TOC was tested (data not shown). The physio-chemical properties of tested sandy loam soil are shown in Table (1).

Table 1. Some physio-chemical properties of tested soil as an initial state

\begin{tabular}{|c|c|c|c|c|c|c|c|c|c|c|c|}
\hline \multirow{2}{*}{ Property } & $\mathbf{p H}$ & EC & $\mathrm{OC}$ & $\mathbf{N}$ & $\mathbf{P}$ & $\mathbf{K}$ & $\mathrm{Ca}$ & $\mathbf{F e}$ & Mn & Zn & \multirow{2}{*}{$\begin{array}{c}\mathrm{CEC} \\
\left(\mathrm{cmol}^{+} / \mathrm{k}\right)\end{array}$} \\
\hline & (1: 2.5) & $\left(\mathrm{dS} \mathrm{m}^{-1}\right)$ & \multicolumn{2}{|c|}{$\left(\mathrm{g} \mathrm{kg}^{-1}\right)$} & \multicolumn{6}{|c|}{$\left(\mathrm{mg} \mathrm{kg}^{-1}\right)$} & \\
\hline Value & 7.75 & 2.35 & 8.75 & 0.78 & 15.40 & 72.20 & 82.60 & 6.00 & 3.60 & 2.00 & 8.00 \\
\hline \multicolumn{3}{|c|}{$\mathrm{pH}=$ soil reaction } & $=$ soil sal & \multicolumn{3}{|c|}{$\mathrm{OC}=$ organic carbon } & \multicolumn{3}{|c|}{ CEC $=$ cation exchange capacity } & & \\
\hline & all values & e average of 1 & th seaso & & & & & & & & \\
\hline
\end{tabular}

The soil water-holding capacity was measured by saturating each pot with water and left $48 \mathrm{~h}$ to be drained then its weight was recorded. The water-holding capacity in each pot was $35.8 \%$ (soil: water w/w). Soil moisture content was maintained at approximately $90 \%$ of water-holding capacity by daily weighing of each pot and compensates the evapo-transpiration water. 


\section{Yield Traits and Quality}

To measure the sweet pepper plants growth and their yield characteristics of both seasons, plant samples were taken randomly from each treatment 75 days after transplanting. The leaves number/ plant were manually counted and its leaf area $\left(\mathrm{m}^{2}\right)$ was measured using a digital Planimeter. Plant dry weight (g) was assessed after oven-drying at $70{ }^{\circ} \mathrm{C}$ until constant weight was reached. At harvesting, the pepper plants in each treatment were taken and their yield in terms of fruit number and fruit weight/ plant was recorded.

Total chlorophyll and carotenoids were extracted and determined according to the methods described by (Moran, 1982). using $80 \%$ (v/v) acetone to homogenize samples centrifuged at $10,000 \mathrm{~g}$ for $10 \mathrm{~min}$. Absorbance readings of the extracts was measured at 663, 645 and 470 nm using a UV60A UV-visible recording spectrometer (Shimadzu, Kyoto, Japan).

Relative water content (RWC) of the tissue was measured according to (Weatherly, 1950) using fully-expanded leaf discs. Discs were weighed (fresh mass; FM) and immediately floated on double-distilled water in Petri dishes for $24 \mathrm{~h}$, in the dark, to be saturated. Any adhering water was gently dried and the turgid mass (TM) was recorded. Dry mass (DM) was taken after drying the discs at $70^{\circ} \mathrm{C}$ until reaching a constant weight. RWC was then calculated using the following formula:

$$
\mathrm{RWC}(\%)=[(\mathrm{FM}-\mathrm{DM}) /(\mathrm{TM}-\mathrm{DM})] \times 100
$$

Membrane stability index of plant tissues (MSI) was determined according to the methods of (Gnanasiri et al. 1990), using two equivalent samples of fully-expanded leaf tissues. One sample was placed in test-tubes containing double-distilled water. The content of the test-tube was then heated at $40^{\circ} \mathrm{C}$ in a water bath for $30 \mathrm{~min}$, and the electrical conductivity $\left(\mathrm{EC}_{1}\right)$ of the solution was recorded using a conductivity bridge. The other one was boiled at $100^{\circ} \mathrm{C}$ for $10 \mathrm{~min}$, and the conductivity was measured $\left(\mathrm{EC}_{2}\right)$, and $\mathrm{MSI}$ was calculated using the following formula:

$$
\mathrm{MSI}=[1-(\mathrm{EC} 1 / \mathrm{EC} 2)] \times 100
$$

Alpha-tocopherol ( $\alpha$ TOC) concentration was measured using $900 \mathrm{ml}$ of extraction solvent ( $n$-hexane-ethyl acetate, $n$-hexane), that was mixed with $100 \mathrm{ml}$ of ethyl acetate, and then 20 mg of butylated hydroxyl toluene (BHT) was dissolved in this solvent mixture. Using R-TOC, standard solutions $(20-200 \mu \mathrm{g} / \mathrm{ml})$ were prepared from stock solutions $(50 \mathrm{mg} / 100 \mathrm{ml}$ $n$-hexane). According to the method of (Konings et al. 1996), samples were prepared and saponified. Samples were sliced and dried in an oven at $40{ }^{\circ} \mathrm{C}$ and homogenized, and then $5 \mathrm{~g}$ from each sample was suspended in $30 \mathrm{ml}$ of water in a 500-ml conical flask. To the flask, 21 $\mathrm{g}$ of $\mathrm{KOH}$ dissolved in $100 \mathrm{ml}$ of ethanol was added and then $0.25 \mathrm{~g}$ of ascorbic acid $\mathrm{g}^{-1}$ test portion was added for protecting from oxidation and mixed. At $80{ }^{\circ} \mathrm{C}$, saponification was done for $40 \mathrm{~min}$ and the samples were immediately cooled to room temperature. Water (300 $\mathrm{ml}$ ) was added to bring the ethanol/water ratio to 0.3 and then $n$-hexane/ethyl acetate [9:1 (3 $\times 100 \mathrm{ml}$ )] was added, and the mixtures were extracted 3 times using a separator funnel. Organic phases were combined and washed with 100-ml portions of water until free of alkali, determined by where the reaction of washes to phenolphthalein was neutral (no visible pink 
color). Organic phases were then filtered through anhydrous sodium sulphate into a beaker. The filtrates were evaporated to dryness under reduced pressure (at $40{ }^{\circ} \mathrm{C}$ ). The residues were dissolved in $20 \mathrm{ml}$ of $n$-hexane (HPLC grade) and stored in a freezer at $-20{ }^{\circ} \mathrm{C}$. The $\alpha \mathrm{TOC}$ was determined using an HPLC system of Waters Bondapak $\mathrm{C}_{18}$ reverse-phase column. The mobile phase (methanol/water 94:6) was used at a flow rate of $1.5 \mathrm{ml} \mathrm{min}{ }^{-1}$ and the UV detector was set at $292 \mathrm{~nm}$ (Ching and Mohamed, 2001).

Ascorbic acid concentration (AsA) was resolved in fully-expanded leaves following the method of (Mukherjee and Choudhuri 1983). A sample of $500 \mathrm{mg}$ was extracted with $10 \mathrm{ml}$ of $6 \%(\mathrm{w} / \mathrm{v})$ trichloro acetic acid (TCA). The extract was then mixed with $2 \mathrm{ml}$ of $2 \%(\mathrm{w} / \mathrm{v})$ dinitrophenylhydrazine, followed by the addition of 1 drop of $10 \%(\mathrm{w} / \mathrm{v})$ thiourea in $70 \%$ (v/v) ethanol. The mixture was then boiled for $15 \mathrm{~min}$ in a water bath. After cooling to room temperature, $5 \mathrm{ml}$ of $80 \%(\mathrm{v} / \mathrm{v}) \mathrm{H}_{2} \mathrm{SO}_{4}$ was added at $0{ }^{\circ} \mathrm{C}$. The absorbance was recorded at $530 \mathrm{~nm}$.

Glutathione (GSH) concentration was also measured using a fully-expanded leaf tissue by the method of (Griffth, 1980). Fresh $50 \mathrm{mg}$ sample was homogenized in $2 \mathrm{ml}$ of $2 \%(\mathrm{v} / \mathrm{v})$ metaphosphoric acid and centrifuged at $17,000 \times g$ for $10 \mathrm{~min}$. The supernatant was neutralized by $10 \%(\mathrm{w} / \mathrm{v})$ sodium citrate and three replicate determinations were made. Each $1.0 \mathrm{ml}$ assay was consisted of $700 \mu \mathrm{l}$ of $0.3 \mathrm{ml} \mathrm{M} \mathrm{NADPH}, 100 \mu \mathrm{l}$ of $6 \mathrm{ml} \mathrm{M}$ 5,5'-dithio-bis-2-nitrobenzoic acid, $100 \mu \mathrm{l}$ distilled water and $100 \mu \mathrm{l}$ of extract. The assay was stabilized at $25^{\circ} \mathrm{C}$ for $3-4 \mathrm{~min}$. Ten $\mu \mathrm{l}$ of $50 \mathrm{Units} \mathrm{ml}^{-1} \mathrm{GSH}$ reductase was added and the absorbance was recorded at $412 \mathrm{~nm}$.

Free proline was acquired based on the method of (Bates et al. 1973). Samples were grinded in $3 \%(\mathrm{v} / \mathrm{v})$ sulphosalicylic acid, followed by centrifugation at $10,000 \times g$ for $10 \mathrm{~min}$. In a test-tube, a 2-ml of freshly prepared acid-ninhydrin solution was added to $2 \mathrm{ml}$ of the supernatant. The tubes were incubated in a water bath at $90^{\circ} \mathrm{C}$ for $30 \mathrm{~min}$, and the reactions were terminated in an ice-bath. Reaction mixtures were then extracted with $5 \mathrm{ml}$ of toluene and vortex-mixed for $15 \mathrm{~s}$. At room temperature, the tube was allowed to stand for at least 20 min in the dark to separate the toluene and aqueous phases. The toluene phase was then collected carefully into a test tube and the absorbance of the toluene phase was read at 520 nm using a Bausch and Lomb-2000 Spectronic Spectrophotometer.

Total soluble sugars assessments were carried out according to (Irigoyen et al. 1992). Samples were homogenized in $5 \mathrm{ml}$ of $96 \%$ (v/v) ethanol, washed with $5 \mathrm{ml} 70 \%$ (v/v) ethanol. The extracts were then centrifuged at $3500 \times \mathrm{g}$ for $10 \mathrm{~min}$, and the supernatants were stored at $4{ }^{\circ} \mathrm{C}$ prior to determination. Reaction mixture of $0.1 \mathrm{ml}$ of the ethanolic extract and 3 $\mathrm{ml}$ of freshly-prepared anthrone reagent [150 mg anthrone plus $100 \mathrm{ml}$ of $72 \%$ (v/v) sulphuric acid] were placed in a boiling water bath for $10 \mathrm{~min}$, and then cooled. The absorbance was recorded at $625 \mathrm{~nm}$ using a Bausch and Lomb-2000 Spectronic Spectrophotometer.

Concentrations of $\mathrm{Na}^{+}$and $\mathrm{K}^{+}$were calculated using $0.2 \mathrm{~g}$ dried leaves that were digested with sulphuric acid in the presence of $\mathrm{H}_{2} \mathrm{O}_{2}$ (Wolf, 1982). The mixture was then diluted with distilled water. The concentrations of $\mathrm{Na}^{+}$and $\mathrm{K}^{+}$were measured directly using Flame Spectrophotometry (Lachica et al., 1973). Concentration of $\mathrm{Ca}^{+2}$ was determined using a 


\section{Macrothink}

Perkin-Elmer Model 3300 Atomic Absorption Spectrophotometer (Chapman and Pratt, 1961).

Superoxide dismutase (SOD; EC 1.15.1.1) activity was assessed by assessing the inhibition of the photochemical reduction of nitro bluete trazolium (NBT) (Giannopilitis and Ries, 1977; Beyer and Fridovicht, 1987). One unit of SOD activity was defined as the amount of enzyme required for the reduction of $50 \% \mathrm{NBT}$. Activity of SOD was expressed as $\triangle \mathrm{A}_{564} \mathrm{~min}^{-1} \mathrm{~g}^{-1}$ protein. Catalase (CAT; EC 1.11.1.6) activity was determined by measuring the $\mathrm{H}_{2} \mathrm{O}_{2}$ consumption (Nakano and Asada, 1981). The reaction mixture consisted of $25 \mathrm{ml} \mathrm{M}$ Tris-acetate buffer, $\mathrm{pH} 7.0,0.8 \mathrm{ml} \mathrm{M}$ Na-EDTA and $20 \mathrm{mM} \mathrm{H}_{2} \mathrm{O}_{2}$. The enzyme assay was performed at $25^{\circ} \mathrm{C}$. Activity of CAT was expressed as $\Delta \mathrm{A}_{290} \mathrm{~min}^{-1} \mathrm{~g}^{-1}$ protein.

Ascorbate peroxidase (APX; EC 1.11.1.11) activity was assessed by the method of (Rao et al. 1996) by recording the optical density at $290 \mathrm{~nm}$ and the APX activity was expressed as $\Delta \mathrm{A}_{290} \mathrm{~min}^{-1} \mathrm{~g}^{-1}$ protein. Glutathione reductase (GR; EC 1.6.4.1) activity was measured after monitoring the oxidation of NADPH for 3 absorbances taken at $340 \mathrm{~nm}$. Activity of GR was expressed as $\Delta \mathrm{A}_{340} \mathrm{~min}^{-1} \mathrm{mg}^{-1}$ protein.

The obtained data was analyzed by analysis of variance analysis (ANOVA) and differences between the means were compared by Fisher least-significant difference (LSD) test at a probability level of $95 \%$. Significance levels were expressed as $P \leq 0.05$, data was deemed significant at $P \leq 0.05$.

\section{Results}

The effect of $\alpha$-TOC on growth parameters and yield of pepper plants irrigated by diluted sea water are appeared in Table 2. The data revealed that pepper plants irrigated by sea water $\left(\mathrm{EC}=8.0 \mathrm{dS} \mathrm{m}^{-1}\right)$ resulted in a noteworthy reduction in the assessed growth variables (leaves number $\&$ area, plant dry weight, Fruit number and yield). The results also illustrated that foliar application of $\alpha$-TOC on pepper plants improved growth and yield under salinity stress. The maximum increase was recognized in the treatment irrigated by tap water and sprayed by $1 \mathrm{mM} \alpha$-TOC. 
Table2. Effect of $\alpha$-tocopherol application on some growth and yield characteristics of Capsicum annuum plants irrigated by diluted sea water

\begin{tabular}{|c|c|c|c|c|c|c|}
\hline $\begin{array}{l}\text { Growth } \\
\text { season }\end{array}$ & Treatments & $\begin{array}{c}\text { Leaves No. } \\
\text { plant }^{-1}\end{array}$ & $\begin{array}{c}\text { Leave area } \\
(\mathrm{m} 2)\end{array}$ & $\begin{array}{l}\text { Plant dry } \\
\text { weight (g) }\end{array}$ & $\begin{array}{c}\text { Fruit number } \\
\text { plant }^{-1}\end{array}$ & $\begin{array}{l}\text { Fruit yield } \\
\text { plant }^{-1}(\mathrm{~g})\end{array}$ \\
\hline \multirow{4}{*}{2014} & $\mathbf{T W}_{\mathrm{I}}+\mathbf{T W}_{\mathrm{F}}$ (control) & $47.3 \mathrm{~b}$ & $0.15 \mathrm{~b}$ & $65.4 \mathrm{~b}$ & $11.7 \mathrm{~b}$ & $352 \mathrm{~b}$ \\
\hline & $\mathbf{T W}_{\mathbf{I}}+\mathbf{T O C}_{\mathrm{F}}$ & 52.2 a & 0.17 a & $72.1 \mathrm{a}$ & 12.9 a & 388 a \\
\hline & $\mathbf{S W}_{\mathbf{I}}+\mathbf{T W}_{\mathbf{F}}$ & $26.7 \mathrm{~d}$ & $0.08 \mathrm{~d}$ & $34.7 \mathrm{~d}$ & $6.1 \mathrm{~d}$ & $102 \mathrm{~d}$ \\
\hline & $\mathrm{SW}_{\mathrm{I}}+\mathrm{TOC}_{\mathrm{F}}$ & $38.3 \mathrm{c}$ & $0.11 \mathrm{c}$ & $53.5 \mathrm{c}$ & $8.9 \mathrm{c}$ & $190 \mathrm{c}$ \\
\hline \multirow{7}{*}{2015} & $\mathbf{T W}_{\mathrm{I}}+\mathbf{T W}_{\mathrm{F}}($ control $)$ & $48.5 \mathrm{~b}$ & $0.16 \mathrm{~b}$ & $73.2 \mathrm{~b}$ & $12.2 \mathrm{~b}$ & $364 \mathrm{~b}$ \\
\hline & $\mathbf{T W}_{\mathrm{I}}+\mathbf{T O C}_{\mathrm{F}}$ & 53.1 a & 0.19 a & 81.6 a & $14.0 \mathrm{a}$ & 396 a \\
\hline & $\mathbf{S W}_{\mathbf{I}}+\mathbf{T W}_{\mathbf{F}}$ & $26.9 \mathrm{~d}$ & $0.08 \mathrm{~d}$ & $39.1 \mathrm{~d}$ & 5.8d & $111 \mathrm{~d}$ \\
\hline & $\mathbf{S W}_{\mathrm{I}}+\mathbf{T O C}_{\mathrm{F}}$ & $39.2 \mathrm{c}$ & $0.12 c$ & $59.8 \mathrm{c}$ & $9.4 \mathrm{c}$ & $203 c$ \\
\hline & \multicolumn{2}{|c|}{$\mathrm{TW}_{\mathrm{I}}=$ tap water for irrigation } & \multirow{2}{*}{\multicolumn{3}{|c|}{$\begin{array}{l}T_{W}=\text { tap water for spray } \quad S_{\mathrm{I}}=\text { sea water } \\
\text { values are mean of } 5 \text { numbers }\end{array}$}} & \\
\hline & \multicolumn{2}{|c|}{ TOC $_{F}=\alpha$-tocopherol for spray } & & & & \\
\hline & \multicolumn{5}{|c|}{ value followed by different latters are significantly diffe rent } & \\
\hline
\end{tabular}

In terms of photosynthetic pigment, relative water content and membrane stability index of pepper plants that sprayed by $\alpha$ TOC and irrigated by tap water subsequently caused an increase in total chlorophyll, carotenoids, relative water content and membrane stability index compared to other treatments (Table 3). Spraying of $\alpha$ TOC to the salt-stressed pepper plants induced significant increase in total chlorophyll, carotenoids, relative water content and membrane stability index compared to unsprayed plants.

Table 3. Effect of $\alpha$-tocopherol application on photosynthetic pigments and tissue health (relative water content and membrane stability index) of Capsicum annuum plants irrigated by diluted sea water

\begin{tabular}{|c|c|c|c|c|c|}
\hline $\begin{array}{c}\text { Growth } \\
\text { season }\end{array}$ & Treatments & $\begin{array}{c}\text { Total } \\
\text { chlorophylls }\end{array}$ & $\begin{array}{c}\text { Total } \\
\text { carotenoids }\end{array}$ & RWC (\%) & MSI (\%) \\
\hline \multirow{4}{*}{2014} & $\mathbf{T W}_{\mathrm{I}}+\mathbf{T W}_{\mathrm{F}}($ control $)$ & $2.11 \mathrm{~b}$ & $0.51 \mathrm{~b}$ & $74.2 \mathrm{a}$ & $67.4 \mathrm{a}$ \\
\hline & $\mathbf{T W}_{\mathbf{I}}+\mathbf{T O C}_{\mathbf{F}}$ & $2.44 \mathrm{a}$ & 0.58 a & 76.1 a & $70.3 \mathrm{a}$ \\
\hline & $\mathbf{S W}_{\mathbf{I}}+\mathbf{T W}_{\mathbf{F}}$ & $0.84 \mathrm{~d}$ & $0.34 \mathrm{~d}$ & $45.3 \mathrm{c}$ & $49.8 \mathrm{c}$ \\
\hline & $\mathbf{S W}_{\mathrm{I}}+\mathrm{TOC}_{\mathrm{F}}$ & $1.73 \mathrm{c}$ & $0.43 \mathrm{c}$ & $61.5 \mathrm{~b}$ & $59.5 \mathrm{~b}$ \\
\hline \multirow{4}{*}{2015} & $\mathbf{T W}_{\mathrm{I}}+\mathbf{T} \mathbf{W}_{\mathrm{F}}$ (control) & $2.26 \mathrm{~b}$ & $0.53 \mathrm{~b}$ & $75.2 \mathrm{a}$ & $68.5 \mathrm{a}$ \\
\hline & $\mathbf{T W}_{\mathrm{I}}+\mathbf{T O C}_{\mathrm{F}}$. & $2.58 \mathrm{a}$ & $0.60 \mathrm{a}$ & $77.0 \mathrm{a}$ & $71.0 \mathrm{a}$ \\
\hline & $\mathbf{S W}_{\mathbf{I}}+\mathbf{T} \mathbf{W}_{\mathbf{F}}$ & $0.86 \mathrm{~d}$ & $0.31 \mathrm{~d}$ & $46.1 \mathrm{c}$ & $48.2 \mathrm{c}$ \\
\hline & $\mathbf{S W}_{\mathbf{I}}+\mathbf{T O C}_{\mathrm{F}}$ & $1.69 \mathrm{c}$ & $0.42 \mathrm{c}$ & $63.2 \mathrm{~b}$ & $58.6 \mathrm{~b}$ \\
\hline
\end{tabular}

\begin{tabular}{lll}
\hline $\mathrm{TW}_{\mathrm{I}}=$ tap water for irrigation & $\mathrm{TW}_{\mathrm{F}}=$ tap water for s pray & $\mathrm{SW}_{\mathrm{I}}=$ sea water for irrigation
\end{tabular} $\mathbf{T O C}_{\mathrm{F}}=\alpha$-tocophe rol for spray $\mathrm{RWC}=$ relative water content $\mathrm{MSI}=$ membrane stability index values are mean of 5 numbers value followed by diffe rent latters are significantly diffe rent

The results in Table 4 show that sprayed the pepper plants by $\alpha$ TOC under water stress led to an increase ascorbic acid, glutathione and free proline and total soluble sugars compared to the unsprayed plants. Also, the results revealed that, there was a significant increase in all leaf concentrations of non-enzymatic antioxidants and osmoprotectants contents when treat the plants by $\alpha$ TOC under normal conditions. 
Table 4. Effect of $\alpha$-tocopherol application on leaf concentrations of non-enzymatic antioxidants \& osmoprotectants, ascorbic acid, glutathione, free proline and total soluble sugars in Capsicum annuum plants irrigated by diluted sea water.

\begin{tabular}{|c|c|c|c|c|c|c|}
\hline $\begin{array}{c}\text { Growth } \\
\text { season }\end{array}$ & Treatments & TOC & ASA & GSH & Free proline & Soluble sugars \\
\hline \multirow{4}{*}{2014} & $\mathbf{T W}_{\mathrm{I}}+\mathbf{T W} \mathbf{F}_{\mathrm{F}}($ control $)$ & $25.4 \mathrm{~d}$ & $0.67 \mathrm{c}$ & $5.21 \mathrm{c}$ & $44.3 \mathrm{c}$ & $21.3 \mathrm{c}$ \\
\hline & $\mathbf{T W}_{\mathrm{I}}+\mathrm{TOC}_{\mathrm{F}}$ & $56.6 \mathrm{~b}$ & 0.68 c & $5.26 \mathrm{c}$ & $44.5 \mathrm{c}$ & $21.9 \mathrm{c}$ \\
\hline & $\mathbf{S W}_{\mathbf{I}}+\mathbf{T} \mathbf{W}_{\mathbf{F}}$ & $34.1 c$ & $1.01 \mathrm{~b}$ & $7.82 \mathrm{~b}$ & $71.7 \mathrm{~b}$ & $34.5 \mathrm{~b}$ \\
\hline & $\mathbf{S W}_{\mathbf{I}}+\mathbf{T O C}_{\mathbf{F}}$ & 77.5 a & $1.26 \mathrm{a}$ & 8.98 a & $94.2 \mathrm{a}$ & 42.8 a \\
\hline \multirow{4}{*}{2015} & $\mathbf{T W}_{\mathrm{I}}+\mathbf{T W} \mathbf{F}_{\mathrm{F}}($ control $)$ & $28.4 \mathrm{~d}$ & $0.75 \mathrm{c}$ & $5.85 \mathrm{c}$ & $42.1 \mathrm{c}$ & $25.1 \mathrm{c}$ \\
\hline & $\mathbf{T W}_{\mathbf{I}}+\mathbf{T O C}_{\mathbf{F}}$ & 58.4 b & 0.72 c & $5.90 \mathrm{c}$ & $43.0 \mathrm{c}$ & $24.9 \mathrm{c}$ \\
\hline & $\mathbf{S W}_{\mathbf{I}}+\mathbf{T} \mathbf{W}_{\mathbf{F}}$ & $36.2 \mathrm{c}$ & $1.18 \mathrm{~b}$ & $7.92 \mathrm{~b}$ & $67.9 \mathrm{~b}$ & $42.1 \mathrm{~b}$ \\
\hline & $\mathbf{S W}_{\mathbf{I}}+\mathbf{T O C}_{\mathbf{F}}$ & $76.3 \mathrm{a}$ & $1.47 \mathrm{a}$ & $9.48 \mathrm{a}$ & 83.2 a & $62.2 \mathrm{a}$ \\
\hline \multicolumn{2}{|c|}{$T W_{I}=$ tap water for irrigation } & \multicolumn{2}{|c|}{$T W_{F}=$ tap water for spray } & \multicolumn{2}{|c|}{ SW $_{\mathrm{I}}=$ sea water for irrigation } & \\
\hline \multirow{2}{*}{\multicolumn{2}{|c|}{$\begin{array}{l}\text { TOC }_{F}=\alpha \text {-tocophe rol for spray } \\
\text { values are mean of } 5 \text { numbers }\end{array}$}} & \multicolumn{2}{|c|}{ ASA $=$ as corbic acid } & \multicolumn{2}{|c|}{ GSH = glutathione } & \\
\hline & & & lue follo & d by different & rs are signi & tly different \\
\hline
\end{tabular}

Table (5) shows that irrigated pepper plants by diluted sea water led to a significant reduce in shoot concentrations of $\mathrm{K}, \mathrm{Ca}, \mathrm{K} / \mathrm{Na}$ and $\mathrm{Ca} / \mathrm{Na}$, while shoot concentrations of $\mathrm{Na}$ significantly increased in contrast to the plants grown under other treatments. Cultivation of pepper in the presence of $\alpha$ TOC led to significant increase in shoot concentrations of $\mathrm{K}, \mathrm{Ca}$, $\mathrm{K} / \mathrm{Na}$ and $\mathrm{Ca} / \mathrm{Na}$ ratio and a decrease concentration of $\mathrm{Na}$ compared to other plants grown without spraying $\alpha$ TOC and irrigated by tap water or diluted sea water.

Table 5. Effect of $\alpha$-tocopherol application on shoot concentrations of $\mathrm{K}$, Ca and $\mathrm{Na}$ in Capsicum annuum plants irrigated by diluted sea water

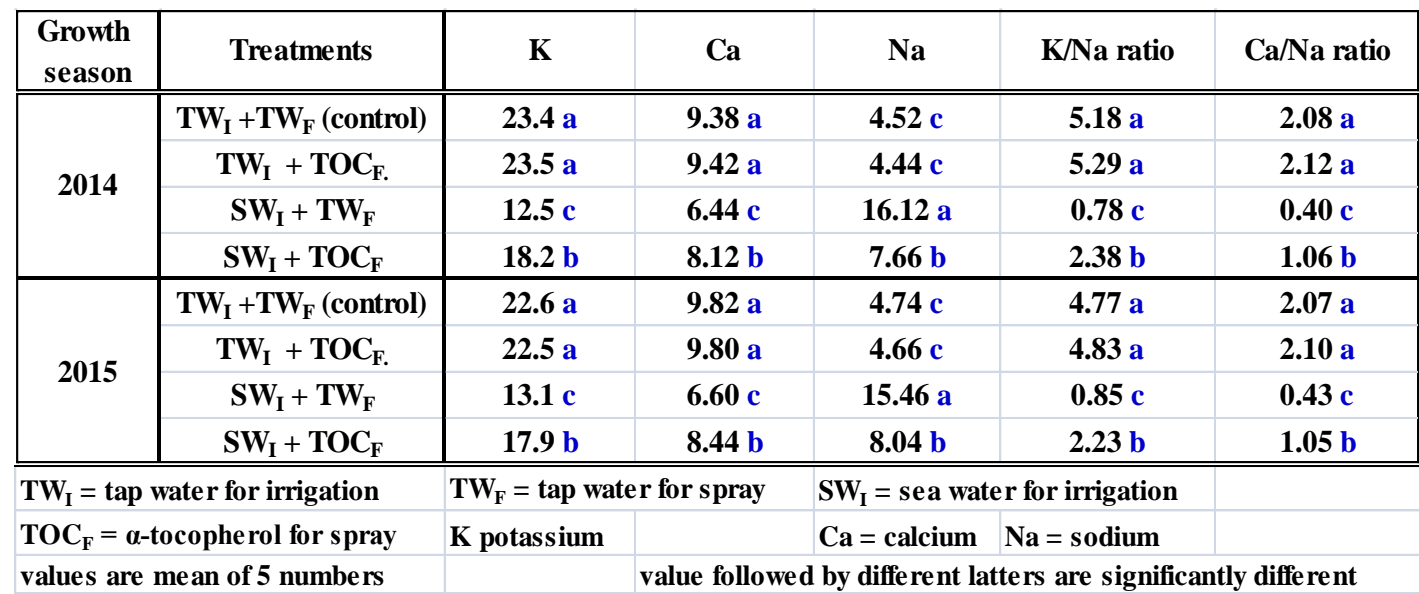


The activities of superoxide dismutase (SOD), catalase (CAT), ascorbate peroxidase (APX) and glutathione reductase (GR) are shown in Table 6 . Under saline conditions $\left(\mathrm{ECe}=8.0 \mathrm{dS} \mathrm{m}^{-1}\right)$, the foliar application of $\alpha$-TOC considerably improved the activities of SOD, CAT, APX as well as GR (9.31, 50.2, 62.5 and $32.6 \mathrm{~min}^{-1} \mathrm{~g}^{-1}$ protein, respectively) of pepper plants compared to those irrigated and sprayed by tap water (control treatment) since the corresponding values were $3.8,34.5,41.8$ and $20.3 \mathrm{~min}^{-1} \mathrm{~g}^{-1}$ protein.

Table 6. Effect of $\alpha$-tocopherol application on the activities of superoxide dismutase, catalase, ascorbate peroxidase and glutathione reductase in Capsicum annuum plants irrigated by diluted sea water

\begin{tabular}{|c|c|c|c|c|c|}
\hline $\begin{array}{c}\text { Growth } \\
\text { season }\end{array}$ & Treatments & SOD & CAT & APX & GR \\
\hline \multirow{4}{*}{2014} & $\mathbf{T W}_{\mathbf{I}}+\mathbf{T W}_{\mathrm{F}}$ (control) & $3.85 \mathrm{~d}$ & $34.5 \mathrm{~d}$ & $41.8 \mathrm{~d}$ & $20.3 \mathrm{~d}$ \\
\hline & $\mathbf{T W}_{\mathbf{I}}+\mathbf{T O C}_{\mathrm{F}}$ & $5.24 \mathrm{c}$ & $39.8 \mathrm{c}$ & $48.6 \mathrm{c}$ & $23.4 \mathrm{c}$ \\
\hline & $\mathbf{S W}_{\mathbf{I}}+\mathbf{T} \mathbf{W}_{\mathbf{F}}$ & 8.22 b & $46.2 \mathrm{~b}$ & $56.2 \mathrm{~b}$ & $28.4 \mathrm{~b}$ \\
\hline & $\mathbf{S W}_{\mathrm{I}}+\mathrm{TOC}_{\mathrm{F}}$ & 9.31a & 50.2 a & $62.5 \mathbf{a}$ & 32.6a \\
\hline \multirow{4}{*}{2015} & $\mathbf{T W}_{\mathrm{I}}+\mathbf{T} \mathbf{W}_{\mathrm{F}}$ (control) & $3.55 \mathrm{~d}$ & $33.2 \mathrm{~d}$ & $39.2 \mathrm{~d}$ & $22.6 \mathrm{~d}$ \\
\hline & $\mathbf{T W}_{\mathbf{I}}+\mathbf{T O C}_{\mathrm{F}}$ & $4.86 \mathrm{c}$ & $38.4 \mathrm{c}$ & $46.2 \mathrm{c}$ & $25.4 \mathrm{c}$ \\
\hline & $\mathbf{S W}_{\mathbf{I}}+\mathbf{T} \mathbf{W}_{\mathbf{F}}$ & $7.53 \mathrm{~b}$ & $44.8 \mathrm{~b}$ & $55.6 \mathrm{~b}$ & $31.2 \mathrm{~b}$ \\
\hline & $\mathbf{S W}_{\mathbf{I}}+\mathrm{TOC}_{\mathrm{F}}$ & 8.82 a & $49.4 \mathrm{a}$ & $64.2 \mathrm{a}$ & $35.6 \mathrm{a}$ \\
\hline \multicolumn{2}{|c|}{$T W_{I}=$ tap water for irrigation } & \multicolumn{2}{|c|}{$T W_{F}=$ tap water for spray } & \multicolumn{2}{|c|}{$\mathrm{SW}_{\mathrm{I}}=$ sea water for irrigation } \\
\hline \multicolumn{2}{|c|}{ TOC $_{F}=\alpha$-tocopherol for spray } & \multicolumn{2}{|c|}{ SOD $=$ s upe roxide dismutase } & CAT $=$ catalase & \\
\hline \multicolumn{2}{|c|}{ APX = ascorbate peroxidase } & \multicolumn{2}{|c|}{ GR = glutathione reductase } & & \\
\hline \multicolumn{2}{|c|}{ values are mean of 5 numbers } & \multicolumn{4}{|c|}{ value followed by different latters are significantly different } \\
\hline
\end{tabular}

\section{Discussion}

Concerning pepper plants growth and their yield, salinity effects occur by stimulating the over production of reactive oxygen species (ROS) through various organelles and enzymes (Rao,2006).In order to avoid these effects alongside other previously stated damages, the plants attempt to adopt several resistance strategies; include ion homeostasis, osmotic adjustment, and enhancing the antioxidant defense system (Xiong and Zhu, 2002). In the current study, the reduce in leaves number or their area, plant dry weight, fruit number and yield per plant (Table 2 ) caused by saline irrigation water $\left(\mathrm{EC}=8.0 \mathrm{dS} \mathrm{m}^{-1}\right)$ could be ascribed to the osmotic effect of salt stress that elevated $\mathrm{Na}$ concentration in mean time reduced $\mathrm{Ca}, \mathrm{K}$, $\mathrm{K} / \mathrm{Na}$ and $\mathrm{Ca} / \mathrm{Na}$ (Table 5) created imbalance state of water content in the stressed plants. This phenomena includes, ionic imbalance, stomatal closure, reduction in photosynthesis, reserve of toxic ions and accordingly growth inhibition (Rady et al., 2013; Semida and Rady, 2014 and Semida et al., 2014).

Salinity limits plant development by its harmful effects on numerous physiological and biochemical actions, antioxidant magnitude, including photosynthesis (Orabi and Abdelhamid, 2014), resulting in damaging growth cells which, therefore, cannot perform their necessary roles (Chen and Murata, 2002). Spraying the pepper plants with $1 \mathrm{mM} \boldsymbol{\alpha}$-TOC significantly improved all plant growth characteristics (fruit number and its weight) resulting in an enhancement in the final yield (Table 2). (Sakr and El-Metwally, 2009) illustrated that $\boldsymbol{\alpha}$-TOC relieved the harmful effects of high salinity stress on the growth of wheat plants and 
increased plant dry matter accumulation in salt soil. $\boldsymbol{\alpha}$-TOC is a main vitamin E compound located in the leaf chloroplasts. $\boldsymbol{\alpha}$-TOC as an antioxidant, that deactivates photosynthesis-derived reactive oxygen species (ROS), and prevents the enhance in lipid peroxidation by scavenging lipid peroxyl radicals in thylakoid membranes. $\boldsymbol{\alpha}$-TOC is considered as an important part of the plant defense machinery, which maintains the integrity and normal function of the photosynthetic apparatus (Liu et al., 2008). In addition, K+ ions are known activators of numerous enzymes that are essential for photosynthesis and respiration; thus, the reduction in $\mathrm{K}+$ ion concentrations (Table 5) could result in an inhibition of photosynthesis and, eventually, a reduction of growth (Salisbury and Ross, 1992).

Regarding photosynthetic pigmentation, acquired data showed that salinity induced a decrease in total chlorophyll, carotenoids, while $\boldsymbol{\alpha}$-TOC application positively influenced these parameters (Table 3). These results are in approval with those postulated by (Rady et al., 2013). Carotenoids and chlorophyll contents reduced under salinity through the reduction of chlorophyll biosynthesis (Abd El-Mageed and Semida, 2015), leading to a lower absorption of daylight by the chloroplast and led to impairing photosynthesis (Semida et al., 2015). The effect of salt soil stress on the photosynthetic pigments may be due to the effect of salinity on the actions of photosynthetic enzymes, and reduced $\mathrm{CO}_{2}$ partial pressure in the leaves caused by stomatal closure (DeRidder, and Salvucci, 2007). Also, (Desingh and Kanagaraj 2007) indicated that salinity stress might affect the photosynthesis by causing, a disorientation of the lamellar system of chloroplasts and a loss of chloroplast integrity leading to a diminution in the activities of photosystems. Application of $\boldsymbol{\alpha}$-TOC could relieve the inhibitory effect of salinity (Table 3). $\boldsymbol{\alpha}$-TOC may interfere with the protection of the chloroplasts and their membrane against salt toxicity and aid in maintaining their integrity (Hassanein, 2009) or vitamins protect chloroplasts from oxidative damage (Munne and Bosch, et al., 2001). Also $\boldsymbol{\alpha}$-TOC as an antioxidant protected photosynthetic machinery from salt-induced ROS. Under salinity stress, $\boldsymbol{\alpha}$-TOC significantly increased the concentrations of carotenoids, which are considered free radical scavenger (Sakr and El-Metwally, 2009), controlling the intensity of free radicals as well as peroxides (Apel and Hirt, 2004) and augmenting plant capacity to reduce the damage caused by ROS, which in turn increment chlorophyll contents in the leaves (Orabi and Abdelhamid, 2014).

The reduced growth and yields of pepper plants grown under diluted sea water have been associated with the reduction in membrane stability index (MSI) and relative water content (RWC) (Tables 2 and 3), while the application of $\boldsymbol{\alpha}$-TOC solved these adverse effects and increased RWC and MSI. This decrease in leaf RWC could be related to the lessened availability of water under stress conditions (Shalhevet, 1993), or to a root system that was not able to compensate the water lost via transpiration through a reduction in its water-absorbing surface (Gadallah, 2000). Stress-induced reductions in the RWC of leaves indicated a loss in cell turgidity that resulted in limited availability of water for cell extension (Katerji et al., 1997). The $\boldsymbol{\alpha}$-TOC spraying enabled the plant leaves to maintain a high level of RWC by regulating the leaf osmolality, assuaging the negative effects of salt stress. The effect of TOC may be due to it serving as an osmo-protectant to prevent cell damage from dehydration (Krieger-Liszkay and Trebst, 2006). The increase in water potential and osmotic 
potential might help in stabilization of the associated proteins and increase photosynthesis processes (Ashfaque et al., 2014). Under salt stress, soil salts trigger the osmotic stress, and the over increase of ionic in the cells causes salt stress. In addition, (Abd El-Mageed and Semida 2015) reported a decrease in relative water content (RWC) and membrane stability index (MSI) under the effect of salt stress. This result confirms the findings in Table 3.In the present study, increased proline concentrations and total soluble were observed in pepper plants growing under salt stress (Table 4). The increase in leaf proline concentrations under saline stress might be caused by increased proline synthesis from glutamate, decreased use for protein synthesis, or enhanced protein turnover.

Some researchers have reported a higher proline content with foliar application of $\boldsymbol{\alpha}$-TOC acting as a solute for intercellular osmotic adjustment (Orabi and Abdelhamid, 2014 and Taie et al., 2013). Total soluble sugars are considered key osmolytes for osmotic adjustment. The accumulation of total soluble sugars is a common phenomenon under stress conditions (Haq et al. 2011 and $\mathrm{Wu}$ et al. 2013) conveyed an increase in total soluble sugars with a progressive escalation in salinity, which played an important role in osmo-regulation and abridged the osmotic potential (Martino et al., 2003). High salinity caused both hyper-ionic and hyperosmotic stress leading to plant death (Hasegawa et al., 2000). It has been stated that plants grown under saline conditions are affected in three ways: reduced water potential in the root zone causing water deficit stress; phyto-toxicity of $\mathrm{Na}^{+}$and $\mathrm{Cl}^{-}$ions; and nutrient imbalances due to lowered uptake and transport of nutrients. Sodium ions compete with $\mathrm{K}^{+}$ ions for the binding sites essential for cellular functions (Munns, 2002). However, data in Table 5 showed that irrigation of pepper plants with diluted sea water caused significant increases in $\mathrm{Na}$ concentrations in leaves, with significant decreases in $\mathrm{N}$ and $\mathrm{K}+$ ion concentrations, and in the $\mathrm{N} / \mathrm{Na}$ and $\mathrm{K} / \mathrm{Na}$ ratio. Reductions in $\mathrm{K}^{+}$ion concentrations and $\mathrm{K} / \mathrm{Na}$ ratios under saline conditions were confirmed by (Osman and Rady 2012 and Abdelhamid et al. 2013). It is known that a high concentration of $\mathrm{Na}$ ions in plant tissues under saline conditions decreases the $\mathrm{K} / \mathrm{Na}$ ratio, which in turn impairs the selectivity of root cell membranes and results in the passive accumulation of $\mathrm{Na}$ ions in plant organs (Farouk, 2011). The increase in Na uptake under salinity was accompanied by corresponding declines in $\mathrm{N}$ and $\mathrm{K}$ concentrations, showing an ostensible antagonism of $\mathrm{N}$ and $\mathrm{K}$ ions against $\mathrm{Na}$ ions (Alam, 1994). Potassium ions are the main cation and are an essential component of the osmotic potential of cells (Reggiani et al., 1995). Exogenous foliar applications of TOC lightened the detrimental effects of salinity to ion concentrations due to a reduction in $\mathrm{Na}$ ion accumulation (Table 5), as well as an increase in the concentrations of $\mathrm{K}^{+}$and $\mathrm{Ca}$ which led to an increase in $\mathrm{K} / \mathrm{Na}$ and $\mathrm{Ca} / \mathrm{Na}$ ratios compared to control plants and plants grown under the salinity level without TOC treatment. The positive effects of TOC arose through its role in increasing osmotic tolerance and/or through regulating processes such as the absorption of nutrients from the soil solution. Furthermore, the beneficial effects of TOC may be due to its roles in improving membrane permeability and increasing soluble protein concentrations which protected membranes and membrane-bound enzymes. TOC thus protected plants against salt toxicity through its roles in maintaining the structural integrity of the plasma membrane and controlling the uptake of $\mathrm{Na}^{+}$and other toxic ions (Buschmann and Lichtenthaler, 1979). 


\section{Mll Macrothink}

Journal of Agricultural Studies

ISSN 2166-0379

2018, Vol. 6, No. 1

Data of the present study shows that $\boldsymbol{\alpha}$-TOC spraying increased the activities of SOD, CAT, APX, ASA and GR compared to the salt stressed-control plants (Table 4 and 6). These increased activities of antioxidant enzymes may contribute compensations to pepper plants and enable a better performance in the various aspects of growth and metabolism as they defend against the harmful effect of salinity stress, mainly through the proliferation in these enzyme activities together with the increase of some antioxidant substances. The ASA and GSH (the substrates of the Halliwell-Asada cycle) also act as antioxidants in an isolated manner, meaning that they are directly involved in the reduction of ROS during different levels of stress (Del Río et al., 2006). This situation is reflected within the evaluation of the total contents of $\boldsymbol{\alpha}$-TOC, ASA and GSH in the current study (Table 4). The specified compounds are increased by the application of $\boldsymbol{\alpha}$-TOC under salt stress, lessening the accumulation of $\mathrm{O}_{2}$. The ASA can directly remove $\mathrm{O}_{2}$ and $\mathrm{H}_{2} \mathrm{O}_{2}$ in a non-enzymatic manner (Foyer et al., 1991). $\alpha$-TOC has suggested to play a major role in chloroplastic antioxidant of plants, contributing to preserve an adequate redox station in chloroplasts, and to maintaining thylakoid membrane structure and function during plant development and in the plants' response to stress (Munne'-Bosch, 2005, Orabi \& Abdehamid 2014 and Semida et al., 2016) recorded increases in the antioxidant enzymes in response to $\boldsymbol{\alpha}$-TOC application on bean and plants against oxidative stress.

\section{Conclusion}

Salt stress tolerance in pepper plants, was improved by the exogenous of $\boldsymbol{\alpha}$-TOC that was effective in boosting adaptability to soil salinity stresses by better chlorophyll, enzymatic and non-enzymatic antioxidants, plant growth and productivity. This might be attributed to cytokinins mediated staying green effect. Findings of this study suggested that the exogenous spraying of $\boldsymbol{\alpha}$-TOC, at the level of $1 \mathrm{mM}$, promotes the expression of stress-response genes and increases salt stress tolerance in pepper plants. While concurrently concluding that $\boldsymbol{\alpha}$-TOC spraying enhanced the expression of ROS-related stress-response genes, and that it is an effective means of enhancing resistance to subsequent stress.

\section{References}

Abdallah, M. M., El-monem, A. A., Hassanein, R. A. \& El-Bassiouny, H. M. S. (2013). response of sunflower plant to the application of certain vitamins and arbuscular mycorrhiza under different water regimes, Australian Journal of Basic and Applied Sciences, 7(2), 915-932.

Abdelhamid, M. T., Rady, M. M., Osman, A. Sh. \& Abdalla, M. A. (2013). Exogenous application of proline alleviates salt-induced oxidative stress in Phaseolus vulgaris L. plants. The Journal of Horticultural Science and Biotechnology, 88(4)439-446. https://doi.org/10.1080/14620316.2013.11512989

Abd El-Mageed, T. A. \& Semida, W. M. (2015). Effect of deficit irrigation and growing seasons on plant water status, fruit yield and water use efficiency of squash under saline soil. Scientia Horticulturae, 186.89-100. https://doi.org/10.1016/j.scienta.2015.02.013 
Abraham, E., Rigo, G., Szekely, G., Nagy, R.,Koncz,C., \& Szabados, L. (2003). Light dependent induction of proline biosynthesis by abscisic acid and salt stress is inhibited by brassinosteroid in Arabidopsis. Plant Molecular Biology, 51(3), 363-372. https://doi.org/10.1023/A:1022043000516

Alam, S. M. (1994). Nutrient uptake by plants under stress conditions. In: Handbook of Plant and Crop Stress. (Passarakli, M., Ed.). Marcel Dekker, New York, NY, USA. 227-246.

Apel, K. \& Hirt, H. (2004). Reactive oxygen species: metabolism, oxidative stress and signal transduction. Annual Review of Plant Biology, 55,373-399.

https://doi.org/10.1146/annurev.arplant.55.031903.141701

Arancon, N. Q., Edwards, C. A., Lee, S. \& Byrne, R. (2006). Effects of humic acids from vermicomposts on plant growth. European Journal of Soil Biology, 46, 65-69.

https://doi.org/10.1016/j.ejsobi.2006.06.004

Asada, K. (1992). Ascorbate peroxidase-a hydrogen peroxide scavenging enzyme in plants. Physiologia Plantarum. 85,235-241. https://doi.org/10.1111/j.1399-3054.1992.tb04728.x

Asada, K. (1999). The water-water cycle in chloroplasts: Scavenging of active oxygens and dissipation of excess photons. Annual review of plant biology, 50,601-639.

https://doi.org/10.1146/annurev.arplant.50.1.601

Ashfaque, F., Khan, M.I.R.,\& Khan, N.A. (2014). Exogenously applied H2O2 promotes proline accumulation, water relations, photosynthetic efficiency and growth of wheat (Triticum aestivum L.) under salt stress. Annual Research \& Review in Biology. 4(1),105-120. https://doi.org/10.9734/ARRB/2014/5629

Athar, H.R., Khan, A.,\& Ashraf, M. (2008). Exogenously applied ascorbic acid alleviates salt-induced oxidative stress in wheat. Environmental and Experimental Botany, 63(1) 224-231.

https://doi.org/10.1016/j.envexpbot.2007.10.018

Bacilio, M., Rodriguez, H., Moreno, M., Hernandez, J. P. \& Bashan, Y. (2004). Mitigation of salt stress in wheat seedlings by a gfp-tagged Azospirillum lipoferum. Biology and Fertility, 40 (3),188-193.https://doi.org/10.1007/s00374-004-0757-z

Bates, L., Waldren, R. P. \& Teare, I.D. (1973). Rapid determination of free proline for water-stress studies. Plant and Soil, 39 (1), 205-207. https://doi.org/10.1007/BF00018060

Beyer, W. F. Jr. \& Fridovich, I. (1987). Assaying for superoxide dismutase activity: some large consequences of minor changes in conditions. Analytical biochemistry, 161(2), 559-66. https://doi.org/10.1016/0003-2697(87)90489-1

Buschmann, C. \& Lichtenthaler, H. K. (1979). The influence of phytohormones on prenyl lipid composition and photosynthetic activities of thylakoids. In: Advances in the Biochemistry and Physiology of Plant Lipids. (Appelgvist, L. A. and Liljenberg, C., Eds.). Elsevier, Amsterdam, The Netherlands. 145-150. 


\section{$\triangle$ Macrothink}

Journal of Agricultural Studies

ISSN 2166-0379

2018, Vol. 6, No. 1

Castañón-Nájera, G., Latournerie-Moreno, L., Mendoza-Elos, M., Vargas-López, A. \& Cárdenas-Morales, H.(2008).Sampling and characterization of pepper chilli (Capsicum spp) in Tabasco, Mexico. International journal of experimental botany, 77 (1), 189-202

Chapman, H. D., \& Pratt, P. F. (1961). Methods of Analysis for soils, plants and water. Univ. California, Berkeley, CA, USA.

Chen, T.H.H. \& Murata, N. (2002). Enhancement of tolerance of abiotic stress by metabolic engineering of betaines and other compatible solutes. Current opinion in plant biology, 5 (3), $250-257$.

https://doi.org/10.1016/S1369-5266(02)00255-8

Ching, L. S. \& Mohamed, S. (2001). Alpha-tocopherol content in 62 edible tropical plants. Journal of Agricultural and food Chemistry, 49(6), 3101-5.https://doi.org/10.1021/jf000891u

Del Río, L.A., Sandalio, L.M. \& Corpas, F.J. (2006). Reactive oxygen species and reactive nitrogen species in peroxisomes production scavenging, and role in cell signaling. Plant Physiol. 141(2), 330-335.https://doi.org/10.1104/pp.106.078204

DeRidder, B. P.,\& Salvucci, M. (2007). Modulation of Rubisco activase gene expression during heat stress in cotton (Gossypium hirsutum L.) involves post-transcriptional mechanisms. Plant Science, 172 (2), 246-252.https://doi.org/10.1016/j.plantsci.2006.08.014

Desingh, R.,\& Kanagaraj, G. (2007). Influence of salinity stress on photosynthesis and antioxidative systems in two cotton varieties. Gen. Appl. Plant Physiology. 33(3-4), 221-234.

Edelstein, M., Ben-Hur,M., Cohen, R., Burger,Y. \& Revina, I. (2005). Boron and salinity effects on grafted and non-grafted melon plants. Plant and Soil, 269 (1),273-284. https://doi.org/10.1007/s11104-004-0598-4

Ejaz, B., Sajid, Z.A.,\& Aftab,F. (2012). Effect of exogenous application of ascorbic acid on antioxidant enzyme activities, proline contents, and growth parameters of Saccharum spp. hybrid cv. HSF-240 under salt stress. Turkish Journal of Biology, 36 (6), 1-11.

Estan, M. T., Martinez-Rodriguez, M. M., Perez-Alfocea,F., Flowers, T. J. \& Bolarini, M. C. (2005). Grafting raises the salt tolerance of tomato through limiting the transport of sodium and chloride to the shoot. Journal of Experimental Botany, 56(412), 703-712.

https://doi.org/10.1093/jxb/eri027

Fang, Z., Bouwkamp, J. \& Solomos, T. (1998). Chlorophyllase activities and chlorophyll degradation during leaf senescence in non-yellowing mutant and wild-type of Phaseolus vulgaris L. Journal of Experimental Botany, 49 (420),503-510.

Farouk, S. (2011). Ascorbic acid and -tocopherol minimize salt induced wheat leaf senescence. Journal of Stress Physiology and Biochemistry, 7,58-79

Foyer, C.H., Lelandais, M., Edwards, E.A. \& Mullineaux, P.M. (1991). The role of ascorbate in plants, interactions with photosynthesis and regulatory significance. In: Active oxygen/oxidative stress and plant metabolism (Pell E, Steffen K, Eds.). American Society of 
Plant Physiology, Rockville, MD, 131-144.

Gadallah, M. A. A. (2000). Effects of indole-3-acetic acid and zinc on the growth, osmotic potential and soluble carbon and nitrogen components of soybean plants growing under water deficit. Journal of Arid Environments, 44(4), 451-467.

https://doi.org/10.1006/jare.1999.0610

Giannopolitis, C. N, Ries, S. K. (1977). Plant Physiol.Superoxide dismutases: Occurrence in higher plants, 59(2),309-14.

Gnanasiri, S. Premachandra, H. S., Kounosuke, F. \& Shoitsu, O. (1990).Cell Membrane Stability and Leaf Water Relations as Affected by Phosphorus Nutrition under Water Stress in Maize. Soil Science and Plant Nutrition, 36(4), 661-666.

https://doi.org/10.1080/00380768.1990.10416803

Griffith, O. W. (1980). Determination of glutathione and glutathione disulfide using glutathione reductase and 2-vinylpyridine. Analytical biochemistry, 106(1),207-12.

https://doi.org/10.1016/0003-2697(80)90139-6

Hamdia, A. M., Shaddad, M. A. K. \& Doa., M. M. (2004). Mechanisms of salt tolerance and interactive effects of Azospirillum brasilense inoculation on maize cultivars grown under salt stress conditions. Journal of Plant Growth Regulation, 44 (2), 165-174.

https://doi.org/10.1023/B:GROW.0000049414.03099.9b

Haq, I., Soomro, F., Parveen, N., Dahot, M. U.,\& Mirbahar, A. A. (2011). Certain growth related attributes of micro-propagated banana under different salinity levels. Journal of Botany, 43, 1655-1658.

Hasegawa, P. M., Bressan, R. A., Zhu, J-K. \& Bohnert, H. J. (2000). Plant cellular and molecular responses to high salinity. Annual Review of Plant Physiology and Plant Molecular Biology, 51 (1), 463-469.https://doi.org/10.1146/annurev.arplant.51.1.463

Hassanein, R. A., Bassony, F. M., Barakat, D. M. \& Khalil, R. R. (2009). Physiological effects ofnicotinamide and ascorbic acid on Zea mays plant grown under salinity stress. 1Changes in growth, some relevant metabolic activities and oxidative defense systems. Research Journal of Agriculture and Biological Sciences, 5(1), 72-81.

Hussein, M. M., Abd El-Rheem, Kh. M., Khaled, S. M. \& Youssef, R. A. (2011). Growth and nutrients status of wheat as affected by ascorbic acid and water salinity. Nature and science., 9,64-69.

Jaleel, C. A., Manivannan, P. \& Lakshmanan, G. M. A. (2007). NaCl as a physiological modulator of proline metabolism and antioxidant potential in Phyllanthus amarus. Comptes Rendus Biologies, 330 (11), 806-813.https://doi.org/10.1016/j.crvi.2007.08.009

Irigoyen, J. J., Emerich, D. W. \& Sanchez- Diaz, M. (1992). Water stress induced changes in concentrations of proline and total soluble sugars in nodulated alfalfa (Medicago sativa) plants. Physiologia Plantarum, 84(1), 55-60.

https://doi.org/10.1111/j.1399-3054.1992.tb08764.x 


\section{$\triangle$ Macrothink}

Katerji, N., Van Hoorn, I. W., Hamdy, A., Mastrorilli, M. \& Mou karzel, E. (1997). Osmotic adjustment of sugar beets in response to soil salinity and its influence on stomatal conductance, growth and yield. Agricultural Water Management, 34 (1), 57-69.

https://doi.org/10.1016/S0378-3774(96)01294-2

Khan, M. I. R., Mughal, A., Iqbal, N. \& Khan, N.A. (2013). Potentiality of sulphur containing compounds in salt stress tolerance. In: Ecophysiology and responses of plants under salt stress (Parvaiz A,Azooz MM, Prasad MNV, Eds). Chapter 17, 443-472, Springer.

https://doi.org/10.1007/978-1-4614-4747-4_17

Khan, N.A. (2003). NaCl-inhibited chlorophyll synthesis and associated changes in ethylene evolution and antioxidative enzymes in wheat. Biologia plantarum, 47(3),437-440.

https://doi.org/10.1023/B:BIOP.0000023890.01126.43

Koning, A. J., Roberts, C. J. \& Wright, R. L. (1996). Different subcellular localization of Saccharomyces cerevisiae HMG-CoA reductase isozymes at elevated levels corresponds to distinct endoplasmic reticulum membrane proliferations. Molecular biology of the cell, 7(5),769-89.

https://doi.org/10.1091/mbc.7.5.769

Krieger-Liszkay, A. \& Trebst, A. (2006). Tocopherol is the scavenger of singlet oxygen produced by the triplet states of chlorophyll in the PSII reaction centre. Journal of experimental botany, 57 (8),1677-1684.https://doi.org/10.1093/jxb/er1002

Lachica, M., Aguilar, A.,\& Yanez, J. (1973). Metodos analiticos en la Estacion Experimental del Zaidin. Anal Edad Agrobiol. 32,1033-1047.

Liu, J. \& Zhu, J. K. (1998). A calcium sensor homolog required for plant salt tolerance. Science,280(5371),1943-5.https://doi.org/10.1126/science.280.5371.1943

Liu, X., Hua, X., Guo, J., Qi, D., Wang, L., Liu, Z., Jin. S., Chen, S. \& Liu, G. (2008). Enhanced tolerance to drought stress in transgenic tobacco plants overexpressing VTE1 for increased tocopherol production from Arabidopsis thaliana. Biotechnology letters, 30 (7), 1275-1280.

https://doi.org/10.1007/s10529-008-9672-y

Loggini, B., Scartazza, A., Brugnoli, E. \& Navari-Izzo, F. (1999). Antioxidative defense system, pigment composition, and photosynthetic efficiency in two wheat cultivars subjected to drought. Plant Physiology, 119 (3),1091-1099.

https://doi.org/10.1104/pp.119.3.1091

Maggio, A. S., Yazaki, P., Veronese, F., Ibeas, J. I., Damsz, B., Navasimhan, M.L.,Hasegawa,P.M., Joly,R.J. \& Bressan, R.A. (2002). Does proline accumulation play an active role in stress induced growth reduction. The plant journal. 31(6), 699-712. https://doi.org/10.1046/j.1365-313X.2002.01389.x

Martino, C. D., Delfine, S., Pizzuto, R., Loreto, F. \& Fuggi, A. (2003). Free amino acids and glycinebetaine in leaf osmoregulation of spinach responding to increasing salt stress. 
NewPhytology, 158(3),455-463.https://doi.org/10.1046/j.1469-8137.2003.00770.x

Meyer, R.F. \& Boyer, J.S. (1981). Osmoregulation, solute distribution and growth in soybean seedlings having low water potentials. Planta, 151(5), 82-489.

https://doi.org/10.1007/BF00386543

Mishra, M., Mishra, P. K., Kumar, U. \& Prakash, V. (2009). NaCl phytotoxicity induces oxidative stress and response of antioxidant system in Cicer arietinum L.cv. Abrodbi. Botany Research International, 2(2), 74-82.

Moran, R. (1982). Formulae for determination of chlorophyllous pigments extracted with N, N-dimethylformamide. Plant physiology, 69(6), 1376-1381.

https://doi.org/10.1104/pp.69.6.1376

Mukherjee S. P. \& Choudhuri M. A. (1983). Implications of water stress-induced changes in the levels of endogenous ascorbic acid and hydrogen peroxide in Vigna seedlings. Physiologia Plantarum, 58 (2), 166-170.https://doi.org/10.1111/j.1399-3054.1983.tb04162.x

Munne'-Bosch, S. (2005). The role of a-tocopherols in plant stress tolerance. Journal of plant physiology,162(7),743-748.https://doi.org/10.1016/j.jplph.2005.04.022

Munne'-Bosch, S. \& Alegre, L. (2002). The function of tocopherols and tocotrienols in plants. Critical Reviews in Plant Sciences ,21(1),31-57.https://doi.org/10.1080/0735-260291044179

Munne - Bosch, Schwarz, S., K. \& Algere, L. (2001). Water deficit in combination with high solar radiation leads to midday depression of $\alpha$-tocopherol in field grown lavender (Lavandula stoechas) plants. Functional Plant Biology. 28(4), 315-321.

Munns, R. (2002). Comparative physiology of salt and water stress. Plant, Cell and Environment, 25(2), 239-250.https://doi.org/10.1046/j.0016-8025.2001.00808.x

Munns, R., James, R. \& Läuchli, A. (2006). Approaches to increasing the salt tolerance of wheat and other cereals. Journal of experimental botany, 57(5), 39-47.

https://doi.org/10.1093/jxb/erj100

Munns, R. \& Termat, A. (1986). Whole plant response to salinity. Functional Plant Biology. 13(1), 143-160.https://doi.org/10.1071/PP9860143

Murakeozy, E. P., Nagy, Z., Duhaze, C., Bouchereau, A. \& Tuba, Z. (2003). Seasonal changes in the levels of compatible osmolytes in three halophytic species of inland saline vegetation in Hungary. Journal of Plant Physiology, 160(4),395-401.

https://doi.org/10.1078/0176-1617-00790

Nakano, Y. \&Asada, K. (1981). Hydrogen peroxide is scavenged by ascorbate specific peroxidase in spinach chloroplasts. Plant and cell physiology, 22(5), 867-880

Nardi, S., Pizzeghello,D., Muscolo, A. \&Vianello,A. (2002). Physiological effects of humic substances on higher plants. Soil Biology and Biochemistry, 34(11), 1527-1536.

https://doi.org/10.1016/S0038-0717(02)00174-8 


\section{Macrothink}

Journal of Agricultural Studies

ISSN 2166-0379

2018, Vol. 6, No. 1

Navarro, J. M., Garrido, C., Carvajal, M. \& Martínez, V. (2002). Yield and fruit quality of pepper plants under sulphate and chloride salinity. Horticultural Science and Biotechnology, 77(1), 52-57.

https://doi.org/10.1080/14620316.2002.11511456

Orabi, S. A. \& Abdelhamid, M.T. (2014). Protective role of a-tocopherol on two Vicia faba cultivars against seawater-induced lipid peroxidation by enhancing capacity of anti-oxidative system. Journal of the Saudi Society of Agricultural Sciences, 15 (2), 145-154.

https://doi.org/10.1016/j.jssas.2014.09.001

Osman, A. S. H. \& Rady, M. M. (2012). Ameliorative effects of sulphur and humic acid on the growth, antioxidant levels, and yields of pea (Pisum sativum L.) plants grown in reclaimedsaline soil. Journal of Horticultural Science \& Biotechnology, 87(6),626-632. https://doi.org/10.1080/14620316.2012.11512922

Prado, U.G. (2008). Caracterización morfológica in situ y capacidad germinativa en poblaciones silvestres de Capsicum spp. del estado de Tabasco, Mexico. Tesis MSc. Colegio de Postgraduados, Campus Tabasco, Tabasco, Mexico.

Pérez-Casteñeda, L., Castañón-Nájera,M.G. \& Mayek-Perez,Y. N. (2008). Diversidad morfológica de chiles (Capsicum spp.) de Tabasco, México. Cuadernos de biodiversidad, $n^{o}$ 27 (septiembre 2008); pp. 11-22.https://doi.org/10.14198/cdbio.2008.27.02

Paital, B. \& Chainy, G.B.N. (2010). Antioxidant defenses and oxidative stress parameters in tissues of mud crab (Scylla serrata) with reference to change salinity. Comparative Biochemistry and Physiology Part C: Toxicology \& Pharmacology, 151 (1), 142-151. https://doi.org/10.1016/j.cbpc.2009.09.007

Qadir, M., Ghafoor,A. \& Murtaza,G. (2000). Amelioration strategies for saline soils: a review. Land Degrad Develop, 11(6),501-521. https://doi.org/10.1002/1099-145X(200011/12)11:6<501::AID-LDR405>3.0.CO;2-S

Qiu,D-L., Lin, P. \& Guo, S.Z. (2007). Effects of salinity on leaf characteristics and CO2/H2O exchange of Kandelia candel (L.) Druce seedlings. Journal of Forest Science, 53, 13-19.

Rady, M.M. (2011). Effect of 24-epibrassinolide on growth, yield, antioxidant systemand cadmium content of bean (Phaseolus vulgaris L.) plants under salinity and cadmium stress. Scientia Horticulturae, 129(2), 232-237.https://doi.org/10.1016/j.scienta.2011.03.035

Rady, M.M. (2012). A novel organo-mineral fertilizer can mitigate salinity stress effects for tomato production on reclaimed saline soil. South African journal of botany, 81, 8-14. https://doi.org/10.1016/j.sajb.2012.03.013

Rady, M.M. \& Osman, A. Sh. (2011). Effects of the application of 'cash' on the growth, fruit yield, and nutrient status of tomato (Solanum lycopersicum L.) grown in reclaimed saline soil. The Journal of Horticultural Science and Biotechnology, 86 (6), 626-630.

https://doi.org/10.1080/14620316.2011.11512814

Rady, M. M., Bhavya, Varma, C. \& Howladar, S.M. (2013). Common bean (Phaseolus 
vulgaris $\mathrm{L}$.) seedlings overcome $\mathrm{NaCl}$ stressas a result of presoaking in Moringa oleifera leaf extract. Scientia horticulturae,162, 63-70. https://doi.org/10.1016/j.scienta.2013.07.046

Rady, M. M, Sadak, M.Sh, El-Lethy, S. R, AbdElhamid, E.M. \& Abdelhamid, M. T. (2015). Exogenous a-tocopherol has a beneficial effect on Glycine max (L.) plants irrigated with diluted sea water. The Journal of Horticultural Science and Biotechnology. 90(2), 195-202. https://doi.org/10.1080/14620316.2015.11513172

Reggiani, R., Bozo, S. \& Bertani, A. (1995). The effect of salinity on early seedling growth of seeds of three wheat (Triticum aestivum L.) cultivars. Canadian Journal of Plant Science, 75(1), 175-177.https://doi.org/10.4141/cjps95-029

Rhoades, J. D., Kandiah, A. \& Mashal, M.(1992). The use of saline waters for cropproduction. FAO Irrig Drain, Paper 48.

Rao, K. M., Raghavendra, A. S., \& Reddy, K. J. (Eds.). (2006). Physiology and molecular biology of stress tolerance in plants. Springer Science \& Business Media.

Rao, M. V., Paliyath, G. \& Ormrod, D. P. (1996). Ultraviolet-B-and ozone- induced biochemical changes in antioxidant enzymes of Avabi-dopsis thaliana. Plant physiology, 110 (1), 125-136. https://doi.org/10.1104/pp.110.1.125

Sadak, M. Sh.,\& Dawood, M. G. (2004). Role of ascorbic acid and $\alpha$ tocopherol in alleviating salinity stress on flax plant (Linum usitatissimum L.) Journal of Stress Physiology \& Biochemistry, 10(1), 93-111.

Sadak, M. Sh, Rady, M.M., Badr, N.M. \& Gaballah, M.S. (2010). Increasing sunflower salt tolerance using nicotinamide and a-tocopherol. International Journal of Academic Research, 2(4), 263-270.

Sairam, R. K., Snvastava, G. C., Aganwal, S. \& Meena, R. C. (2005). Differences in antioxidant activity in response to salinity stress in tolerant and susceptible wheat genotypes. Biologia Plantarum, 49(1), 85-91.https://doi.org/10.1007/s10535-005-5091-2

Sairam, R. K. \& Srivastava, G. C. (2001). Water stress tolerance of wheat Triticum aestivum L.: Variation in hydrogen peroxide accumulation and antioxidant activity in tolerant and susceptible genotype. Journal of Agronomy and Crop Science, 186(1), 63-70. https://doi.org/10.1046/j.1439-037x.2001.00461.x

Sakamoto, A. \& Murata, N. (2001). The use of bacterial choline oxidase, a glycinebetaine-synthesizing enzyme, to create stress-resistant transgenic plants. Plant Physiology 125(1), 180-188.https://doi.org/10.1104/pp.125.1.180

Sakr, M.T. \& El-Metwally, M.A. (2009). Alleviation of the harmful effects of soil salt stress on growth, yield and endogenous antioxidant content of wheat plant by application of antioxidants. Pakistan journal of biological sciences: PJBS, 12(8),624-630. https://doi.org/10.3923/pjbs.2009.624.630

Salisbury, F. B. \& Ross, C. W. (1992). Mineral nutrients. In: Plant Physiology. Wadsworth 
Inc., Belmont, CA, USA. 116-135.

Santa-Cruz, A., Martinez-Rodriguez, M. M., Perez-Alfocea,F.,Romero-Aranda, R. \& Bolarin, M. C. (2002). The root stock effect on the tomato salinity response depends on the shoot genotype. Plant Science 162(5), 825-831.

https://doi.org/10.1016/S0168-9452(02)00030-4

Schwabe, K. A., Kan, I. \& Knapp, K.C. (2006). Drainwater management for salinity mitigation in irrigated agriculture. American Journal of Agricultural Economics, 88(1), 133-149.

https://doi.org/10.1111/j.1467-8276.2006.00843.x

Semida, W. M., Abd El-Mageed, T. A., Howladar, S. M., Mohamed, G. F. \& Rady, M. M. (2015). Response of solanum melongena 1. seedlings grown under saline calcareous soil conditions to a new organo-mineral fertilizer. The Journal of Animal \& Plant Sciences, 25(2), 485-493.

https://doi.org/10.21475/ajcs.2016.10.07.p7712

Semida, W. M., Abd El-Mageed, T. A., Howladar, S. M. \& Rady, M. M. (2016). Foliar-applied a-tocopherol enhances salt-tolerance in onion plants by improving antioxidant defence system. Australian Journal of Crop Science, 10(7), 1030-1039.

https://doi.org/10.21475/ajcs.2016.10.07.p7712

Semida, W. M. \& Rady, M. M. (2014). Presoaking application of propolis and maize grain extracts alleviatessalinity stress in common bean (Phaseolus vulgaris L.). Scientia Horticulturae,168,210-217.https://doi.org/10.1016/j.scienta.2014.01.042

Semida, W. M., Taha, R. S., Abdelhamid, M. T. \& Rady, M. M. (2014). Foliar-applied $\alpha$-tocopherol enhances salt-tolerance in Vicia faba L. plants grown under saline conditions. South African Journal of Botany, 95, 24-31. https://doi.org/10.1016/j.sajb.2014.08.005

Semiz,G. D., Suarez, D. L., kara, A. U. \&Yurtseve, E. (2014). interactive effects of salinity and $\mathrm{n}$ on pepper (Capsicum annuum l.) yield, water use efficiency and root zone and drainage salinity. Journal of Plant Nutrition, 37(4), 595-610.

https://doi.org/10.1080/01904167.2013.867985

Shalhevet, J. (1993). Plants under salt and water stress. In: Plant Adaptation to Environmental Stress. (Fowden, L., Mansfield, T. and Stoddart, J., Eds.). Chapman and Hall, London, UK. 133-154.

Singla-Pareek, S. L., Reddy, M. K. \& Sopory, S. K. (2003). Genetic engineering of the glyoxalase pathway in tobacco leads to enhanced salinity tolerance. Proceedings of the National Academy of Sciences, 100(25),14672-14677

https://doi.org/10.1073/pnas.2034667100

Taie, H., Abdelhamid, M. T., Dawood, M. G. \& Nassar, R. M. (2013). Pre-sowing seed treatment with proline improves some physiological, biochemical and anatomical attributes of faba bean plants under sea water stress. Journal of Applied Sciences Research, 9, 
2853-2867

United Nations, Food and Agriculture Organization (2011). Agriculture, Food, and Water: A Contribution to the World Water Development Report, Rome

Weatherley, P. E. (1950). Studies in the water relations of the cotton plant. I. The field measurements of water deficits in leaves. New Phytologist, 49(1), 81-97.

https://doi.org/10.1111/j.1469-8137.1950.tb05146.x

Wise, R.R. \& Naylor, A.W. (1987) Chilling enhanced photo-oxidation. Plant Physiology. 83(2),278-282.https://doi.org/10.1104/pp.83.2.278

Wolf, B. (1982). A comprehensive system of leaf analysis and its use for diagnosing crop nutrients status. Communications in Soil Science and Plant Analysis, 13(12), 1035-1059. https://doi.org/10.1080/00103628209367332

Wu, G., Liang, N., Feng, R. \& Zhang, J. (2013). Evaluation of salinity tolerance in seedlings of sugar beet (Beta vulgaris L.) cultivars using proline, soluble sugars and cation accumulation criteria. Acta Physiologiae Plantarum, 35(9), 2665-2674.

https://doi.org/10.1007/s11738-013-1298-6

Xiong, L. \& Zhu, J.K. (2002). Molecular and genetic aspects of plant responses to osmotic stress. Plant, Cell \& Environment,25(2),131-139.

https://doi.org/10.1046/j.1365-3040.2002.00782.x

Yang, A. F., Duan,X. G., Gu,X. F.,Gao,F. \& Zhang,J. R. (2005). Efficient transformation of beet (Beta vulgaris) and production of plants with improved salt-tolerance. Plant Cell, Tissue and Organ Culture, 83(2), 259-270.https://doi.org/10.1007/s11240-005-6670-9

Yasar, F., Kusvuran, S. \& Elialtioğlu, S. (2006). Determination of antioxidant activities in some melon (Cucumis melo L.) varieties and cultivars under salt stress. The Journal of Horticultural Science and Biotechnology, 81(4), 627-630.

https://doi.org/10.1080/14620316.2006.11512115

Yildrimin, B., Yaser, F., Ozpay, T., Ozpay, D. T., Turkozu, D., Terziodlu, O. \&Tamkoc, A. (2008). Variations in response to salt stress among field pea genotypes (Pisum sativum sp. arvense L.). Journal of Animal and Veterinary Advances, 7(8), 907-910.

Zhu, J.K. (2002). Salt and drought stress signal transduction in plants. Annual review of plant biology, 53(1), 247-273.https://doi.org/10.1146/annurev.arplant.53.091401.143329

\section{Copyright Disclaimer}

Copyright for this article is retained by the author(s), with first publication rights granted to the journal.

This is an open-access article distributed under the terms and conditions of the Creative Commons Attribution license (http://creativecommons.org/licenses/by/4.0/). 